DOI https://doi.org/10.32841/2409-1154.2021.51-1.14

\author{
Koknova T.A., \\ Doctor of Pedagogical Sciences, \\ Professor of Romance and German Philology Department \\ Luhansk Taras Shevchenko National University
}

\title{
STATUS OF ENGLISH CLICHES IN MODERN LINGUISTICS
}

Summary. The article is devoted to the analysis of the status of English clichés in modern linguistics. The main features of clichéd language units are their reproducibility in speech, situational and multi-word character. Linguistic clichés are considered as a part of the phraseological system of language. This approach is most consistently developed by V. Teliya, who distinguishes seven different sections in phraseology, considering language clichés in the hierarchy of phraseological units. Cliché in the given article is defined as one of the types of reproducible statements related to communicative situation. Clear criteria of clichés as a separate class of lexical units are described in the article. In the works of foreign scholars, the term "cliché" is often used as a synonym for the term "idiom" due to their steady nature and frequent reproducibility in speech in the finished form. The concepts of cliché and stamp are both identified and distinguished due to the great similarity of these linguistic units. However, the difference is that the stamps are connected with certain situation, which they have to describe, while the clichés are more independent units that appear in speech situations, more informative, and give a positive value to the text. The information load is a feature of a cliché that distinguishes it from a stamp. The problem of distinguishing clichés from proverbs and sayings, quotations is also considered in the article. Proverbs and sayings refer to both phraseology and clichés. Clichés and quotations are reproducible, but a cliché is a unit of speech, and a quotation is a literal extract from any text; when reproducing a cliché, a language unit from a commonly used thesaurus is used, while the quotation is someone else's words and has its author. Defining the essence of speech clichés, it is concluded that the most appropriate term for all phraseological units is "set-expression", which best reflects the essence of the phraseological units, clichés, stamps, proverbs, sayings and quotations. All these units are characterized by constancy and reproducibility at the lexical and syntactic levels.

Key words: speech clichés, linguistic clichés, idioms, stamps, quotations, phraseological units.

Problem statement. Nowadays the problem of linguistic cliché is of great interest in modern linguistics. The researches of modern scholars suggest that this phenomenon is somewhat ambiguous. The primary task for many researchers in the study of language clichés in various languages is the development and improvement of the terminological base, since there is no specificity and consistency of existing scientific definitions.

Analysis of recent studies. In domestic and foreign linguistics, the problem of linguistic cliché was discussed by such scholars as I. Arnold, V. Krasnykh, B. Gasparov, Yu. Karaulov, E. Kubriakova, V. Teliya, R. Alison. The attention of the scientists to the study of linguistic clichés within such branches as psycholinguistics, text linguistics, discourse theory, lexicology, phraseology, syntax and functional stylistics proves the complexity of this phenomenon and the possibility and necessity of its comprehensive analysis.

The purpose of the article is to analyze the status of English clichés in modern linguistics.

Discussion. The clichéd linguistic units should have some similar characteristics, which determine the status of these units. The main feature of clichéd linguistic units is their reproducibility in speech [1].

In linguistics, there are several different approaches to understanding reproducibility. The first approach is presented by the researchers who believe that speech activity means constantly producing and interpreting new statements that the communicant has never heard before [2]. Thus, speech activity is a creative process of creating unique combinations of speech units, which proves that clichéd units and idiomatic expressions do not exist, since their specific nature is denied.

Another point of view is supported by the scientists who argue that there are some ready-made communicative pieces in memory, which help a person to learn the world and interact with it. These fragments are stored in memory after the first visual contact or auditory perception, and then they are reproduced in speech [3]. Within the framework of this theory, the fact that people communicate with each other exclusively with the help of the clichés or phraseological units seems rather disputable.

In addition to the above-mentioned polar viewpoints, there is another one that can be called a compromise. Some researchers admit a kind of symbiosis of reproducibility and creativity of speech. O. Semenyuk notes that "real speech activity is a kind of continuum, one pole of which is stereotyped, clichéd and almost automatically performed speech, which description, perhaps, demands a small set of terms with a small range of linguistic structures and units. The other pole of this speech activity is innovative, creative, and breaking the established barriers" [4].

Thus, in any language there is a unity and struggle of two tendencies: on the one hand, freedom of creativity of speech community, which is based on the productivity of linguistic forms and models, on the other - the reproduction of ready-made complex forms, coherence, clichés, regular reproducibility. The first tendency allows to develop and create language, the second - saves the efforts of the speakers, replenishes the body of ready-made language units, and is optimal for expressing a concept or thought in a particular speech community [5]. These ready-made units are called clichés, stereotypes, phraseological units, templates, stamps. To understand the essence and the nature of clichés, it is necessary to consider a number of terminological problems.

Speech clichés, like all reproducible linguistic units, can be considered within the phraseological system of the language. Broad understanding of phraseology which includes not only 
the units with rethought components, but also reproducible phrases and expressions in their direct meanings allows such inclusion. The most consistent approach to the content of phraseology is developed by V. Teliya [1], who distinguishes seven different sections of phraseology: Phraseology-1, which studies wholly idiomatic word combinations; Phraseology-2, which studies lexical collocations with an analytical type of meaning; Phraseology-3, which studies clichés close to the combinations studied by Phraseology-2 on the background of standardization; Phraseology-4, which studies newspaper and journalists and writers stamps; Phraseology-5, exploring sayings and proverbs; Phraseology-6, which studies catch phrases. Thus, the speech cliché plays a vital role in the hierarchy of phraseological units, since $\mathrm{V}$. Teliya considers the first four sections of phraseology as linguistic ones [1].

The definition of a cliché in the dictionary also states that the cliché is a unit of phraseological character: "set expressions, perceived as bound units (i.e. entirely reproducible) by all native speakers" [6]. We support N. Vyshnevs'ka's opinion, who understands clichés as a category of statements reproduced in finished form and situational related [7]. From our point of view, situationality is an important feature that distinguishes speech clichés from all other types of clichés.

As N. Sologub admits, clichés are "phraseological units plus something else", and only by defining this "something", we can reveal the specifics of the clichés [8,p. 237]. The study of the scholar suggests quite clear criteria to separate clichés into a separate class of lexical units: 1) reproducibility of clichés in speech, 2) their appearance in specific conditions of a speech act, in typical situations (contexts), 3) the semantics of clichés can be realized exclusively in a real context, 4) weak syntagmatic connection of clichés with the rest of the statement [8, p. 237.]. However, when the clichés are used, their emotive meaning is often concomitant, but not leading. For example, in meta-communicative communication, the main emphasis is made not on the excitement of emotions, but on the activation of various kinds of psychological activity of the interlocutor, aimed at perception, processing, and assimilation of information. The third criterion asserts the deictic nature of the clichés. It means that out of the speech situation, out of the communicative act, the clichés do not have a specific reference, and indicates some possible situation of its functioning only in abstract, general way, which specifies a close connection between the second and the third criteria identified by N. Sologub.

If we consider a cliché as a phraseological unit, then in addition to being reproducible and situational, we must admit that the cliché should also have the feature of bringing several words together, which is underlined by V. Teliya. However, we cannot deny that such units as Sorry, Well, Fine and the like are clichéd. The problem of several words in cliché, in particular, is discussed by E. Selivanova, who believes that clichés are not just set and regularly reproduced expressions, but also "usually compound linguistic units (phrases), which are frequently and fluently used in numerous speech acts, both oral and written" [9].

Consequently, the phraseological status of a cliché, as follows from the above, does not cause serious disagreement among the linguists, while the definition of the concept of a cliche itself is somewhat ambiguous. At the same time, we often encounter the substitution of the concepts, since various researchers do not distinguish between clichés and idioms (proper phraseological units), stamps (templates), stereotypes, proverbs, sayings and quotes.
In the works of foreign scholars, the term "cliché" is almost always used as a synonym for the term "idiom", which is quite polysemantic. Thus, English researchers use it without making any distinction between lexical and grammatical levels to define the groups of words, the meaning of which is difficult or impossible to deduce from the meaning of the same words out of the idiom. For example, foreign scholars under the term "idiom" mean speech anomalies that violate either the rules of grammar or the laws of logic [10]. In the "Longman Dictionary of English Idioms" and "Cambridge International Dictionary of Idioms", idioms are understood as a set group of words that have a meaning different from the meanings of its components, i.e. the main emphasis is on the rethinking of the meanings of the components of the idiom. The authors of one of the manuals on English set expressions, consider idioms as "the term that combines not only phraseological units themselves, but also phrases typical of English speech, like in earnest, what's it all about, at the latest [11].

Such understanding of the meaning of the term "idiom" allows us to state that clichés, due to their stable nature and frequent reproducibility in speech in finished form, are idioms. However, it cannot be claimed that the meanings of all speech clichés are difficult or impossible to deduce from the meanings of the same words out of phrases. For example, the meaning of the speech cliché $I$ don't think we've met (we are not familiar with each other) is easily deduced from the meanings of its components. This fact proves that "cliché" and "idiom" are different concept though having something in common.

Consequently, there is a certain similarity between speech clichés and phraseological units. In our opinion, their similarity is obvious from the constant character of their use. However, the constant character of the units and their use is diverse: in phraseological units it is observed at lexical and grammatical composition level. In addition, clichés are directly related to the communicative situation in which they occur. The difference between clichés and phraseological units is also in imagery. For example, the dictionary of linguistic terms argues that the cliché is an idiom that has lost its imagery, the last stage of the existence of a linguistic unit, when, at first, the borders between the denotative meanings of its components vanish, then the expressiveness (natural to idioms) also fades away due to excessive reproducibility, and finally the expression "freezes", taking on a definite form forever [12, p. 122]. However, not all clichés are devoid of imagery, for example, the I'm all ears cliché contains a vivid metaphor, therefore, in our opinion, this criterion cannot be taken to distinguish between clichés and phraseological units. N. Romanyuk mentions that even the most well-known clichés can in certain situations "be vivid" [13]. At the same time, we agree that many clichés are really devoid of imagery (if you ask me, just a minute).

In linguistic studies the scholars make attempts to both identify and distinguish between the concepts of clichés and stamps. This problem arose as a result of the great similarity of these linguistic units, which, in our opinion, in fact represent a wider layer linguistic units - the class of stereotypes.

In the linguistic dictionary, the concepts of a cliché vs a stamp are identified, and considered in the same dictionary entry, entitled as a "speech stamp", which indicates "a stylistically colored speech expressions, existing in collective consciousness of the speakers of a given language as set, ready for use, and therefore the most convenient means of expressing a certain linguistic content of expres- 
sive and metaphoric nature" [14]. F. Bider gives almost the similar definition, and describes the cliché using the concepts of "stamp", "pattern in the way of thinking", "common hackneyed expression" [15]. The term "pattern", which is used in this definition, is considered by many scholars to be synonymous with the term "stamp".

The identification of these two terms is explained by the fact that they have the same origin, i.e. are characterized by reproducibility. Their difference is in their functions: "stamps are not used in language manipulation or language game, and also do not generate - unlike quotations - additional social meaning" [16]. The stamps are also closely connected with a certain situation, which they have to describe, they are dependent on it, while the clichés are more independent linguistic units.

In addition, clichés have a specific feature of being informative. A cliché, in comparison with a stamp, is considered by most linguists to be informatively more important, attaching a positive-evaluative meaning to the text. This point of view is shared by a number of linguists. In general, this position states that when using clichés, the goal set in the communication process is successfully achieved. Reproducibility of a cliché in various situations is more appropriate, while the use of a stamp is always associated with a negative response from the recipient. N. Vyshnevs'ka argues that it is the textual information load that distinguishes a cliche from a stamp. "A linguistic cliché becomes a stamp, when for one reason or another it has lost its primary, or textual informational load for the interpreter, has become meaningless, insignificant for the recipient of information, in other words, it has become dysfunctional [7].

The similarity of speech stamps and clichés is in their structure: they can be not only speech fragments, but also structural patterns of the use of certain speech units. For example, the stamps vital issue, free world, pillar of society, bulwark of liberty, escalation of war have the same structures: $\mathrm{A}+\mathrm{N}$ and $\mathrm{N}+\mathrm{of}+\mathrm{N}$, and are quite common in newspapers, while clichés Allow me to..., Excuse me..., Remember me to... contain a verb in the imperative and a personal pronoun in objective case.

The problem of distinguishing clichés from proverbs and sayings is that the latter are attributed to both phraseological units and clichés. It should be noted that in linguistics there is no unanimous view on the interpretation of the concepts of "proverb" and "saying". In foreign literature, these concepts are considered as analogous.

The point of view of $\mathrm{N}$. Romanyuk is very interesting when studying the problem of including proverbs and sayings into the group of clichés. The scholar includes proverbs and sayings, as well as various phraseological units (such as sworn enemy, etc.), compound terms (like railway), official word combinations (nevertheless, and the like), and finally, all kinds of "literary", newspaper and colloquial clichés (such as, so to speak, nowadays, etc.) [13] into the group of clichés. The scientist considers that all of the above-mentioned set constructions are purely linguistic phenomena, while proverbs and sayings are related to more complicated speech phenomena.

From our point of view, it is difficult to agree that proverbs and sayings are clichés, since proverbs and sayings, unlike clichés, are expressions of folk wisdom, and, moreover, are short sentences expressing a universally acknowledged truth or mere fact. Clichés, being complete sentences, rarely express any folk wisdom. Clichés help to organize a dialogical interactional space, outline the communicative field according to the requirements of the communicative situation, while proverbs and sayings in most cases only describe, comment or evaluate such situations.

Some researchers attribute various kinds of quotations to clichés. The English cliché researcher E. Partridge [17] defines clichés-quotations as a separate linguistic group. They are borrowed mostly from various works of English literature, for example, from W. Shakespeare's, J. Milton's, as well as the Bible.

In our opinion, it is vital to consider quotations within the framework of phraseology, because of their reproducible nature, although their reproducibility is different from the reproducibility of clichés. The reproducible character of both clichés and quotations, in our opinion, is beyond doubt, but it is necessary to bear in mind the fact that these phenomena are functionally different. Firstly, a cliché is a language unit, and a quotation is a literal excerpt from a text and, therefore, is not a language unit. Secondly, when reproducing a cliché, the speaker extracts a linguistic unit from a commonly used thesaurus, uses it as their own speech; quotations, however, are "someone else's speech," cited from the memory or the original, and are not extracted from the national thesaurus or the vocabulary of a given linguistic personality [1]. Thirdly, the clichés, similar to the phraseological units, and the stamp, are not associated with the name of a person or literary character who has spoken this phrase for the first time, since a quote is always used as an author's phrase. It requires a reference to the author and quotation marks. In case, if a quotation loses its characteristics and acquires phraseological stability, phraseological units appear.

Clichés and colloquial formulas have a lot in common. In the linguistic studies, two approaches are described: the cliché is part of the colloquial formulas, and, on the contrary, the colloquial formulas are a special kind of cliché. A supporter of the first approach is J. Seidl, who, analyzing the concepts of "cliche'" and "speech formula", argues that the first concept is fully included in the second [18]. The supporters of the second approach propose to divide all situational statements into: 1) highly clichéd formulas of speech etiquette, 2) reproduced in finished form and situational related statements, which, from the point of standard lexicology, are completely "free" combinations of words, where each word is used in its direct meaning; 3 ) intermediate phenomena between the first and the second types, having an idiomatic meaning and correlated with traditional phraseological combinations.

There are some other points of view. For example, Alison Wray, in her review on formulaic language [19], defines colloquial formulas as a sequence of words or other elements that are ready-made units, or turn out to be such, that is, stored and reproduced entirely from the memory at the time of their use in speech, and not produced according to the grammar rules of the given language [19]. All of them serve to achieve certain "interactional goals" and to maintain contact [19].

N. Sharmanova classifies set communication expressions as the units of speech etiquette, which means a system of linguistic signs and the rules of their use, adopted in a given society at a given time in order to establish speech contact between communicators and maintain emotionally positive communication in accordance with the speech situation [20].

Admitting the etiquette nature of colloquial formulas, we cannot fully agree with the point of G. Dillon, who attributed pragmatic clichés to the sphere of speech etiquette [21]. From our point of view, one should not reduce clichés to colloquial (speech) formulas, although the latter are the most striking examples of clichés. 
That is why in this work special attention is paid to speech formulas of communication. In fact, it is speech formulas that frequently act as communication controllers, governed by certain rules adopted in a particular society in which the use of certain speech units is dictated by moral and other social laws.

However, as in many other areas of linguistics, the concepts of "clichés" and "colloquial formula" may overlap. The clichés can be used in the meaning of colloquial formulas and vice versa.

Conclusion. Determining the fundamental nature of speech clichés, we have come to the conclusion that a common term for all phraseological units is the term "set-expression", which reflects the essence of phraseological units, clichés, stamps, proverbs, sayings and quotations. All these units show a certain stability at the lexical and syntactic levels, as well as reproducibility. We have found that speech clichés tend to be multi-word units, which can be referred to set expressions studied by phraseology.

Speech clichés differ from all other phraseological units known to linguistics in terms of situational functioning. These units are used in all kinds of situations of everyday communication. The information load also indicates the special status of speech clichés, distinguishing them from other phraseological units.

Thus, as a result of the analysis, it was found that the features given above help to distinguish speech clichés and idioms (the social necessity of using clichés and the criterion of minimum stability at the phraseological level of idioms) from the stamps (lexical units with negative information load), from quotations (impersonal, national and authorial speech units), as well as from speech formulas.

The theoretical review allows to characterize speech clichés as steady, grammatically heterogeneous, regularly reproduced, standard phrases in typical speech situations; reflecting the stereotypes of thinking of the communicants, allowing the speaker to successfully achieve the communicative goal, contributing to the unambiguousness and informative nature of the texts. This interpretation of clichés allows us to assert the indispensability of clichés in creating conditions for successful communication at every stage.

\section{References:}

1. Teliya V.N. Phraseological Entities as a Language of Culture (Methodological Aspects). Europhras 95. Europäische Phraseologie im Vergleich: Gemeinsames Erbe und kulturelle Vielfalt. Bochum : Universitätsverlag Dr. N. Brockmeyer, 1998. S. 783-794.

2. Бацевич Ф. Термінологія комунікативної лінгвістики: аспекти дискурсивного підходу. Вісник Наи. ун-ту «Львів. політ.». 2002. № 453. С. 30-34.

3. Дискурс як когнітивно-комунікативний феномен : монографія / під заг. ред. І.С. Шевченко. Харків : Константа, 2005. 356 с.

4. Семенюк О.А. Основи теорії мовної комунікації : навчальний посібник. Киів : ВЦ «Академія», 2010. 240 с.

5. Яшенкова О.В. Основи теорії мовної комунікації : навчальний посібник. Киів : ВЦ «Академія», 2010. 312 с.

6. Філософський енциклопедичний словник / ред. кол.: В.І. Шинкарук (гол. редкол.) та ін. Киів : Довіра, 2002. 744 с.

7. Вишневська Н.Ю. Кліше як мовна одиниця: проблеми кліше в мовознавстві. Наукові записки Ніжинського держсавного університету імені Миколи Гоголя. Філологічні науки : зб. наук. пр. / відп. ред. Г.В. Самойленко. 2013. Кн. 3. С. 33-36.

8. Сологуб Н.М. Кліше. Українська мова: Енциклопедія / редкол.: В.М. Русанівський, О.О. Тараненко, М.П. Зяблюк та ін. Киів : Українська енциклопедія ім. М.П. Бажана, 2000. 752 c. URL: http:// litopys.org.ua/ukrmova/um.htm (дата звернення: 18.10.2021).
9. Селіванова О.О. Сучасна лінгвістика: термінологічна енциклопедія. Полтава : Довкілля-К, 2006. 716 с.

10. Everaert M., van der Linden E.-J., Schenk A., Schreuder R. Idioms: Structural and Psychological Perspectives. Psychology Press, 2014. $336 \mathrm{p}$.

11. Halliday M.A.K., Cermáková A., Teubert W., Yallop C. Lexicology and Corpus Linguistics, Continuum, 2004. 256 p.

12. Баркасі В.В., Каленюк С.О., Коваленко О.В. Словник лінгвістичних термінів для студентів філологічних факультетів / За ред. С.О. Каленюк. Миколаїв : МНУ імені В.О. Сухомлинського, 2017. $192 \mathrm{c}$.

13. Романюк Н.М. Семіотизація мовних кліше як одиниць когніції, культури і дискурсу (на матеріалі англійської та української мов) : автореф. дис. ... канд. філол. наук. Київ, 2018. 20 с.

14. Баландіна Н.Ф. Функціонально-прагматичний і лінгвоментальний аналіз чеських прагматичних кліше : автореф. дис. ... докт. філол. наук. Київ, 2003. 38 с.

15. Baider F. Cultural Stereotypes and Linguistic Clichés: Their Usefulness in Intercultural Competency. International Journal for Cross-Disciplinary Subjects in Education (IJCDSE). 2013. Vol. 4. Issue 2. P. 1166-1171.

16. Мартинюк А.П. Словник основних термінів когнітивно-дискурсивної лінгвістики. Харків : ХНУ імені В.Н. Каразіна, 2011. 196 с.

17. Partridge E. A dictionary of clichés. URL: http://multilinguablog.com/ wp-content/uploads/2012/07/dictionary-of-cliches.pdf (дата звернення: 12.10.2021)

18. Seidl J., McMordie W. English Idioms and How to Use Them. Oxford University Press, 1978. 272 p.

19. Wray A. Formulaic language in learners and native speakers. Language Teaching. 1999. No. 32(4). P. 213-231. DOI: 10.1017/ S0261444800014154.

20. Шарманова Н. Кліше в українському телепросторі: прагматичний і метакомунікативний вияв. URL: https://movoznavstvo.org.ua/ index.php?option=com_attachments\&task=download\&id=336 (дата звернення: 12.10 .2021$)$.

21. Dillon G.L. Corpus, Creativity, Cliché: Where Statistics Meet Aesthetics. Journal of Literary Semantics: An International Review. Berlin-New York : Walter de Gruyter, 2006. Vol. 35(2). P. 98-110.

\section{Кокнова Т. Статус англомовних кліше у сучасній лінгвістиці}

Анотація. Статтю присвячено аналізу стану англомовних кліше у сучасній лінгвістиці. Головними ознаками клішованих мовних одиниць $€$ їх відтворюваність у мовленні, ситуативність та декількослівність. Мовні кліше розглядаються як частина фразеологічної системи мови. Найбільш послідовно цей підхід розроблений В. Телія, яка виділяє у фразеології сім різних розділів, розглядаючи мовні кліше в ієрархії фразеологічних одиниць. У статті подається визначення кліше як одного з типів відтворюваних у готовому вигляді і ситуативно пов'язаних висловлювань. Охарактеризовано чіткі критерії виділення кліше в окремий клас лексичних одиниць. У роботах зарубіжних учених термін «кліше» часто використовується як синонім терміна «ідіома» 3 огляду на їхній сталий характер і часту відтворюваність у мові в готовому вигляді. Поняття «кліше» і «штамп» як ототожнюють, так і розмежовують через велику схожість цих мовних одиниць. Однак різниця полягає у прив'язаності штампів до певної ситуації, яку вони повинні описати, тоді як кліше $є$ більш самостійними одиницями, які з'являються у мові ситуативно, вони більш інформативні, надають позитивно-оцінне значення у побудові тексту. Саме текстове інформаційне навантаження $\epsilon$ ознакою кліше, що відрізняє його від штампа. Розглянуто проблему відмежування кліше від прислів'їв і приказок, 
цитат. Прислів'я та приказки відносять і до власне фразеологізмів, і до кліше. Кліше і цитати мають відтворюваний характер, але кліше $є$ одиницею мови, а цитата - дослівна витримка з будь-якого тексту, яка не є одиницею мови; для відтворення кліше вживається мовна одиниця із загальновживаного тезаурусу, а цитата $є$ чужою мовою, має свого автора. Визначаючи сутність мовних кліше, було зроблено висновок про те, що загальним терміном для всіх фразео- логічних утворень повинен бути термін «стійка одиниця» (set-expression), який найбільшою мірою відображає сутність власне фразеологізмів, кліше, штампів, прислів'їв, приказок і цитат. Усі перелічені одиниці характеризуються певною стійкістю на лексичному і синтаксичному рівнях, а також відтворюваністю.

Ключові слова: мовна клішованість, мовні кліше, ідіоми, штампи, цитати, фразеологічні одиниці. 